\title{
The role of learned societies in national scholarly publishing
}

Elina Late, Tampere University, Tampere, Finland, email: elina.late@tuni.fi

Laura Korkeamäki, Tampere University, Tampere, Finland, email: laura.korkeamaki@tuni.fi

Janne Pölönen, Federation of Finnish Learned Societies, Helsinki, Finland, email: janne.polonen@tsv.fi

Sami Syrjämäki, Federation of Finnish Learned Societies, Helsinki, Finland, email: sami.syrjamaki@tsv.fi

Cite this article: Late, E., Korkeamäki, L., Pölönen, J., \& Syrjämäki, S. (2020). The role of learned societies in national scholarly publishing. Learned Publishing, 33(1), 5-13.

\section{ABSTRACT}

This study examines the role of learned societies as publishers in Finland based on bibliographic information from two Finnish databases. We studied the share of learned societies' peer-reviewed publication channels (serials with ISSNs and book publishers with distinct ISBN roots) and outputs (journal articles, conference articles, book articles, and monographs) in Finland. We also studied the share of learned societies' open access publications.

In 2018, there were 402 peer-reviewed publication channels in Finland. In 2011-2017, the number of peerreviewed publications from scholars working in Finnish universities and published in Finland was 17,724. Learned societies publish around $70 \%$ of these channels and publications, mostly in the fields of humanities and social sciences. Learned societies in Finland focus on journal publishing, whereas university presses and commercial publishers focus on book publishing. In 2016-2017, 38.4\% of the learned societies' outputs were open access.

This study concludes that Finnish learned societies play an integral part in national scholarly publishing. They play an especially important role in journal publishing, as commercial publishers produce only $2.6 \%$ of Finnish journals and book series, and only $1.4 \%$ of the journal articles from scholars working in Finnish universities.

\section{Key points}

- Finnish learned societies published c.70\% of Finnish peer-reviewed channels (journals, book series, conferences, book publishers) and publications (articles, proceedings, books, monographs) on Finnish channels by scholars working in Finnish universities.

- Most publications from Finnish learned societies are in humanities and social sciences.

- $38.4 \%$ of Finnish learned societies output, 2016-2017, are open access.

- Finnish commercial publishers publish the majority of books but only a fraction of journal articles from Finnish universities. 


\section{INTRODUCTION}

For centuries, learned societies have contributed significantly to scholarly communication. Their role has been integral to the rise and development of scholarly journals (Meadows, 1974, 66-86). After the Second World War, commercial publishers started to gain a bigger share of the journal publishing market. The publishing companies established new scholarly journals and started co-operating with learned societies in publishing (Fyfe et al., 2017, 9-10; Meadows, 1974, 87). In the digital era, the role of commercial publishers has strengthened even more - probably because of their better resources for the transition to digital publishing (Larivière, Haustein, \& Mongeon, 2015).

Publishing is seen as one of the key activities of learned societies (Wiley membership survey, 2015, 3-4). Together with membership fees, they generate income which can be used to fund a society's other activities. For example, learned societies organize conferences, offer support and training for early-career researchers and participate in public engagement (Hewitt, Dingwall \& Turkmendag, 2017). Transition to open access (OA) publishing has an impact on learned societies' economic performance, risking subscription income and membership fees. In UK, an OA working group acknowledged that especially smaller learned societies may lack resources and suitable business models for OA publishing and therefore need time to make the transition (Finch report, 2012, 110).

In September 2018, Plan S (https://www.coalition-s.org/) set a goal that peer-reviewed research publications are published open access or deposited without delay to an open access repository - according to revised guidance - as of January 2021. Plan S applies only to publications that are funded by organizations committed to the initiative. (cOAlition S, 2019.) Plan S raised concern about what will happen to the publishing revenues of learned societies (e.g. Clarke, 2018; Brainard, 2019). The issue is especially relevant in such countries as Finland, where most of the domestic scholarly journals are published by learned societies (Ilva, 2018). For example, Academy of Finland - a national research funder - has endorsed Plan S and its implementation (Academy of Finland, 2018). Wise and Estelle (2019) discussed the possible implications of Plan S for learned societies. Central challenges include OA funding, and a tight schedule for implementing Plan $\mathrm{S}$ which could drive learned societies to make publishing agreements with commercial publishers. In addition, those learned societies, who publish journals in printed form, might lose subscribers/society members and advertising revenues if they decide to shift online-only publishing. (Wise \& Estelle, 2019.)

In this study, we examine the role of learned societies as publishers in Finland. Firstly, we look at learned societies' share of Finnish peer-reviewed publication channels. Here, publication channels are defined as academic journals, book series, conferences and book publishers (Publication Forum, 2019). Secondly, we examine the numbers of peer-reviewed publications in Finland. By publications we mean peer-reviewed articles in journals, proceedings, and books, as well as monographs that are published through publication channels. This study is important as it sheds more light on the numbers and market shares of scholarly publishing on a national level. Our research questions are:

1. What is the share of learned society journals and book publishers of all Finnish peer-reviewed publication channels?

2. What is the role of learned societies compared with commercial publishers, university presses and other type of scholarly publishers operating in Finland?

3. What is the share of learned society journals and book publishers of the Finnish universities' peerreviewed output published in Finland in years 2011-2017?

4. What is the share of OA of learned society publications? 


\section{LITERATURE REVIEW}

Scholarly publishers make publications available to readers in print or digital form. Publishers take care of a number of tasks such as manufacturing, marketing and distribution. Not-for-profit organizations (e.g. learned societies, university presses) use their publishing income for the benefit of the scholarly community. (Mabe, 2009, 9-12.) Therefore, they are sometimes called "mission-driven" organizations (Morris, 2001). Commercial publishers, however, aim to make profit (Mabe, 2009, 9-12). In this study, we focus on learned societies as publishers.

\section{Learned societies as publishers}

Learned societies aim to promote science and disseminate research results (Hopkins, 2011, 259). In some cases, their purpose is also to represent the interests of professionals or increase public understanding of science (Delicado et al., 2014, 445). For researchers, learned societies offer opportunities to share their knowledge and expertise across organizations and geographical areas (Hopkins, 2011; McCarthy \& Rands, 2013). In addition, learned societies offer broader possibilities for university faculty members to advance their profession and scientific field (Willinsky, 2006, 65). The activities of learned societies are numerous. For instance, learned societies do research projects, organize conferences, give prizes and grants, support earlycareer researchers and build networks. Some societies work for the public benefit, e.g. by influencing policymaking and working in co-operation with schools. (Delicado et al., 2014; Hewitt et al., 2017.)

The first scientific journals were established in 1665. Journal des Scavans was established by Denis de Sallo in France. Two months later Henry Oldenburg, the secretary of the Royal Society of London, started publishing Philosophical Transactions. The learned societies became important players in academic/scholarly publishing, as their journals tended to be more successful than other scholarly journals (Csiszar, 2017). For learned societies the motivation in publishing was to promote and disseminate research results more efficiently. (Houghton, 1975, 11-19.) Gradually, the number of learned societies and scholarly journals increased due to the growth of science and specialization of scientific disciplines. (Meadows, 1974, 67-86.) Although the growth of scholarly journals in general was exponential (de Solla Price, 1963), the role of learned societies as publishers weakened after the Second World War as commercial publishers gained more ground and turned scholarly journal publishing into a profitable business (Fyfe et al., 2017, 9). According to Fyfe et al. $(2017,9)$, commercial publishers established new scholarly journals, started selling journals to institutions (e.g. academic libraries) and reached out for the international market. This forced learned societies to rethink their publishing strategy to generate income. (Fyfe et al., 2017, 9.)

As reported in the 2012 STM report, Elsevier estimated that learned societies self-published about 30\% of scholarly articles indexed in Thomson-Reuters (now Clarivate) Journal Citation database. Commercial publishers accounted for $64 \%$, if publishing for learned societies is included. University presses published $4 \%$ of scholarly articles and other publishers $2 \%$ (Ware \& Mabe, 2012, 33).

According to Larivière et al. (2015), big publishers gained market shares from the mid-1990s and onwards as the digital era started in publishing. In 2013, the journals owned by the five largest commercial publishers published more than half of all articles indexed in the Web of Science database. Social sciences were the most $(70 \%)$, and humanities the least $(20 \%)$ dominated fields by the big publishers. The dominance of commercial publishers was also evident in natural and medical sciences, with the exception that one of the top five publishers was a learned society (American Chemical Society) (Larivière et al., 2015.)

Scholarly publishing is an important source of income for many learned societies. In year 2015, 279 out of almost 600 learned societies in UK published peer-reviewed conference proceedings or scientific journals. Their publishing revenues were about $£ 318$ million, which constituted $26 \%$ of their total income. (Johnson \& 
Fosci, 2015; UUK, 2015, 65-66.) It is noteworthy that most (63\%) of the 279 societies published only one peerreviewed journal (UUK, 2015, 66).

Some learned societies have outsourced their publishing activities. For example, in UK only 67 out of 279 learned societies published in-house. The rest were published in co-operation with, e.g. commercial publishers or university presses. (UUK 2015,67 .) According to Willinsky $(2006,57)$, learned societies can benefit from the co-operation with better marketing and distribution for their journals. The downsides are the possible increases in subscription fees which can lead to fewer subscribers (Willinsky, 2006, 57). Larivière et al. (2015) suggested that some smaller learned societies needed commercial partners to ease the transition to digital publishing. Similarly, co-operation can help learned societies' transition to open access publishing if they lack in expertise and financial resources (UUK, 2017, 50).

Piwowar et al. (2018) defined open access as follows: "OA articles are free to read online, either on the publisher website or in an OA repository". In their study they estimated that at least $27.9 \%$ of all scholarly journal articles are open access. When examined by year of publication, the share of OA was greater in more recent articles. For the year 2015 alone, the share of OA journal articles was 44.7\%. (Piwowar et al., 2018.) According to Björk (2019) 30\% of Finnish peer reviewed journals $(\mathrm{N}=334)$ are OA. Other estimates of OA shares can be found from e.g. Martín-Martín et al. (2018) and Johnson, Watkinson and Mabe (2018, 135139).

According to TBI Communications (2014), learned societies' main concerns about open access were the loss of publishing income, the funding of open access fees, competition with big open access publishers, the degradation of quality and diversity of publications, and being associated with low-quality predatory open access publishers. The positive sides of open access were better availability of information, gaining more readers and the possibility to compete with well-known publications. (TBI Communications, 2014, 11-14.)

\section{Learned societies in Finland}

The Finnish learned societies have a national co-operative body called the Federation of Finnish Learned Societies (https://www.tsv.fi/en). It was established in 1899. Its legislative tasks are supporting co-operation of learned societies, developing scientific publishing and dissemination of scientific research, organizing international exchange of publications and increasing awareness and use of scientific research. In 2018, the Federation of Finnish Learned Societies had 282 society members (Federation of Finnish Learned Societies, 2018). These learned societies cover all major academic disciplines. The oldest member societies were established in the 19th century. However, not all learned societies in Finland are members of the federation. The total number of learned societies in Finland is unknown but we estimate that at least $75 \%$ of them are members of the Federation.

In Finland, learned society journals' income consist mainly of subscriptions, membership fees and state subsidies (Ilva, 2018). The state subsidies are allocated by the Ministry of Education and Culture and distributed by the Federation of Finnish Learned Societies. The state subsidies are meant to cover deficits in scholarly journals' publishing budgets and only a few domestic scholarly journals are able to manage without them (Ilva, 2018). This is particularly the case for many societies operating in a specialized field and publishing in the national languages (Finnish or Swedish) as the research communities are relatively small. Publishers operating especially in non-English-speaking countries may face similar challenges in maintaining peerreviewed publication activities in local languages, when research policy, evaluation and funding values international publishing in English (Sivertsen 2018; Kulczycki et al. 2019). 


\section{RESEARCH METHODS}

We collected the research data from two sources. First, to calculate learned societies' share of all Finnish publication channels (research question 1) and to compare learned societies to other scholarly publishers in Finland (research question 2) we collected the bibliographic data of all peer-reviewed publication channels operating in Finland from the register of the Finnish Publication Forum (http://www.julkaisufoorumi.fi/en) in September 2018. The Publication Forum is a classification of peer-reviewed publication channels. It is produced by the Federation of Finnish Learned Societies. The classification includes reliable peer-reviewed channels assigned to one of three-level categories ( $1=$ basic, $2=$ leading and $3=$ top), based on evaluation by the Finnish experts in the field (Auranen \& Pölönen, 2012). The Ministry of Education and Culture uses the classification in the performance-based funding system (PRFS) to allocate part of core-funding annually to universities (Pölönen, 2018). According to the Publication Forum, publication channels are defined as academic journals, book series, conferences and book publishers. Further, the channels are registered as either journals/book series (including journals, book series, and conferences) or book publishers. We limited our analysis to journals/series and book publishers confirmed as peer-reviewed (Publication Forum levels 13 ) and where the country of publisher is identified as Finland. In other words, publication channels from nonFinnish publishers were excluded from this study.

In this study, we divided scholarly publishers of journals/series and books into following types: (i) learned societies, (ii) universities and university presses, (iii) other research organizations, (iv) commercial publishers and $(v)$ other publishers. This was based on bibliographic information included in the Publication Forum register. We defined learned societies as not-for-profit organizations that promote an academic discipline, sub-discipline or field. Most of the learned societies in our research data are members of the Federation of Finnish Learned Societies. We categorized both universities and university presses together, because there are only four university presses in Finland. However, university presses publish the majority of the publication output in this category. Other research organizations are mainly state research institutes, other laboratories and research centers. As "other" we classified publishers such as museums, libraries and trade unions.

Secondly, to calculate the learned societies' share of the Finnish universities' peer-reviewed output published in Finland (research question 3), and to find out the share of OA of learned society publications (research question 4), we collected data from the VIRTA publication information service. VIRTA is a data hub that compiles bibliographic information of all scholarly publications from 54 Finnish research organizations, including all 14 universities (Sïle et al., 2017; Sïle et al., 2018; Pölönen, 2018). Bibliographic information can be accessed in JUULI-portal (http://www.juuli.fi/) and statistical information in VIPUNEN-portal (https://vipunen.fi/en-gb/). From this source, we collected the number of peer-reviewed articles in journals, proceedings and books, as well as monographs published from 2011 to 2017 by the 14 Finnish universities. VIRTA also contains information on the open availability of peer-reviewed publications. More specifically, in 2016-2017 it has been indicated for each publication if it is openly available in Gold or Hybrid OA channel, and if it is deposited in an OA repository (Ilva, 2017). Based on this information we also calculated the share of openly available publications by Finnish universities published in 2016 and 2017.

In VIRTA data, universities have categorized each peer-reviewed publication from 1 to 6 OECD fields of Science. On the basis of the first field we categorized all peer-reviewed articles and monographs as belonging to natural sciences, engineering, medical and health sciences, agriculture, social sciences, and humanities.

The obvious limitation of our study is that it focuses only on Finland. Finland is a small language area with approximately 5.5 million inhabitants. Thus, our results may not be generalized across different types of settings. Since we have not found similar studies done in other countries, in some cases it is difficult to compare our results with previous studies. However, this study aims to start discussion on this subject by 
offering knowledge about the role of learned societies as national scholarly publishers in a small language area such as Finland.

\section{RESULTS}

\section{Finnish peer reviewed channels}

In 2018, there were 402 peer-reviewed publication channels operating in Finland. The majority (69.9\%) were published by learned societies (Table 1). Universities and university presses published almost $14 \%$ and other research organizations $6 \%$ of the publication channels. Surprisingly, only $5.5 \%$ of the channels were published by commercial publishers.

Table 1. The categorization of the publisher types and the number of publication channels operating in Finland in 2018.

\begin{tabular}{lllllll} 
Publisher & \multicolumn{2}{c}{ Book publishers } & \multicolumn{2}{l}{ Journals/series } & \multicolumn{2}{l}{ All channels } \\
\cline { 2 - 7 } & $\mathrm{n}$ & $\%$ & $\mathrm{n}$ & $\%$ & $\mathrm{n}$ & $\%$ \\
\cline { 2 - 7 } Learned society & 30 & 54.5 & 251 & 72.3 & 281 & 69.9 \\
$\begin{array}{l}\text { University, university press } \\
\text { Other research }\end{array}$ & 6 & 10.9 & 50 & 14.4 & 56 & 13.9 \\
$\begin{array}{l}\text { organization } \\
\text { Commercial publisher }\end{array}$ & 4 & 7.3 & 20 & 5.8 & 24 & 6.0 \\
Other & 13 & 23.6 & 9 & 2.6 & 22 & 5.5 \\
\hline Total & 2 & 3.6 & 17 & 4.9 & 19 & 4.7 \\
\hline
\end{tabular}

*Note this only includes complete books, it does not count book chapters separately

Learned societies published most of the channels in both categories (book publishers and journals/series). However, learned societies were mainly focused on journal/series publishing. There were 202 individual societies who published journals/series, although most of them (89\%) published only one type of publication. Only 30 learned societies published books. All in all, 211 different learned societies published books, journals or series in Finland.

\section{Output from Finnish universities}

Scholars working in Finnish universities published a total of 17724 peer-reviewed publications on Finnish channels during the period 2011-2017. The majority (72\%) of the publications were published by learned societies (Table 2). Commercial publishers published $13 \%$ of the output. The share of universities and university presses was $9 \%$, other research organizations $4 \%$ and other publishers $2 \%$. The yearly output of learned societies as well as other publisher types has remained relatively stable over the period 2011-2017 (Figure 1).

Learned societies were the main publishers in every publication type - they published $87 \%$ of journal articles, $73 \%$ of conference papers, and $49 \%$ of book publications (Table 2). Moreover, two of the highest volume journals (Duodecim and Finnish medical journal) are published by learned societies. The output of these two journals covered almost $20 \%$ of the total journal output $(n=10369)$ from Finnish universities during 20112017. However, most Finnish publication channels are rather small and over $50 \%$ of the channels (e.g. 
journals) published only 1-50 articles/book series during 2011-2017. In fact, more than one quarter (27\%) of the journal/book series publishers did not have any publishing activity during the period. The average number of publications per year for journal/series publishers with any publishing activity was 5 (33 publications during 2011-2017).

Likewise, most of the learned societies operating as book publishers in Finland published only a small number of book publications (monographs and articles in books). Almost half of them published less than 10 book publications within the period 2011-2017. The biggest society book publishers are the Finnish historical society (Suomen historiallinen seura) and the Finnish literature society (Suomalaisen kirjallisuuden seura) both published approximately 500 book publications during 2011-2017.

Commercial publishers published 31\% of the Finnish scholarly book publications in 2011-2017. One fourth of the total number of book publications ( $n=6970$ ) were issued by two major commercial publishers in Finland - Gaudeamus and Vastapaino.

Table 2. Output from Finnish universities published in 2011-2017 ( $N=17724)$ by publication type and publisher.

\begin{tabular}{lllllllll}
\multirow{2}{*}{ Publisher } & \multicolumn{2}{l}{ Journal articles } & \multicolumn{2}{l}{ Conference papers } & Book publications* & Total & \\
\cline { 2 - 10 } & $\mathrm{n}$ & $\%$ & $\mathrm{n}$ & $\%$ & $\mathrm{n}$ & $\%$ & $\mathrm{~N}$ & $\%$ \\
\hline Learned society & 9061 & 87.4 & 279 & 72.5 & 3437 & 49.3 & 12777 & 72.1 \\
University, university press & 331 & 3.2 & 85 & 22.1 & 1209 & 17.3 & 1625 & 9.2 \\
Other research organization & 606 & 5.8 & 12 & 3.1 & 111 & 1.6 & 729 & 4.1 \\
Commercial publisher & 150 & 1.4 & 0 & 0.0 & 2177 & 31.2 & 2327 & 13.1 \\
Other & 221 & 2.1 & 9 & 2.3 & 36 & 0.5 & 266 & 1.5 \\
\hline Total & 10369 & 100 & 385 & 100 & 6970 & 100 & 17724 & 100 \\
\hline
\end{tabular}

*This figure includes both complete books (e.g. monographs) and separate book chapters.

There are some clear differences in the publishing profiles of the different publisher types (Figure 2). Learned societies, other research organizations, and other publishers focused on publishing journals. Commercial publishers and universities/university presses focused on book publishing. More than $90 \%$ of the publications published by commercial publishers were monographs and articles in edited volumes. University presses focused on publishing especially doctoral theses. Conference publishing was in the minority in Finland. Worth noting is that commercial publishers did not publish any conference publications in Finland. 


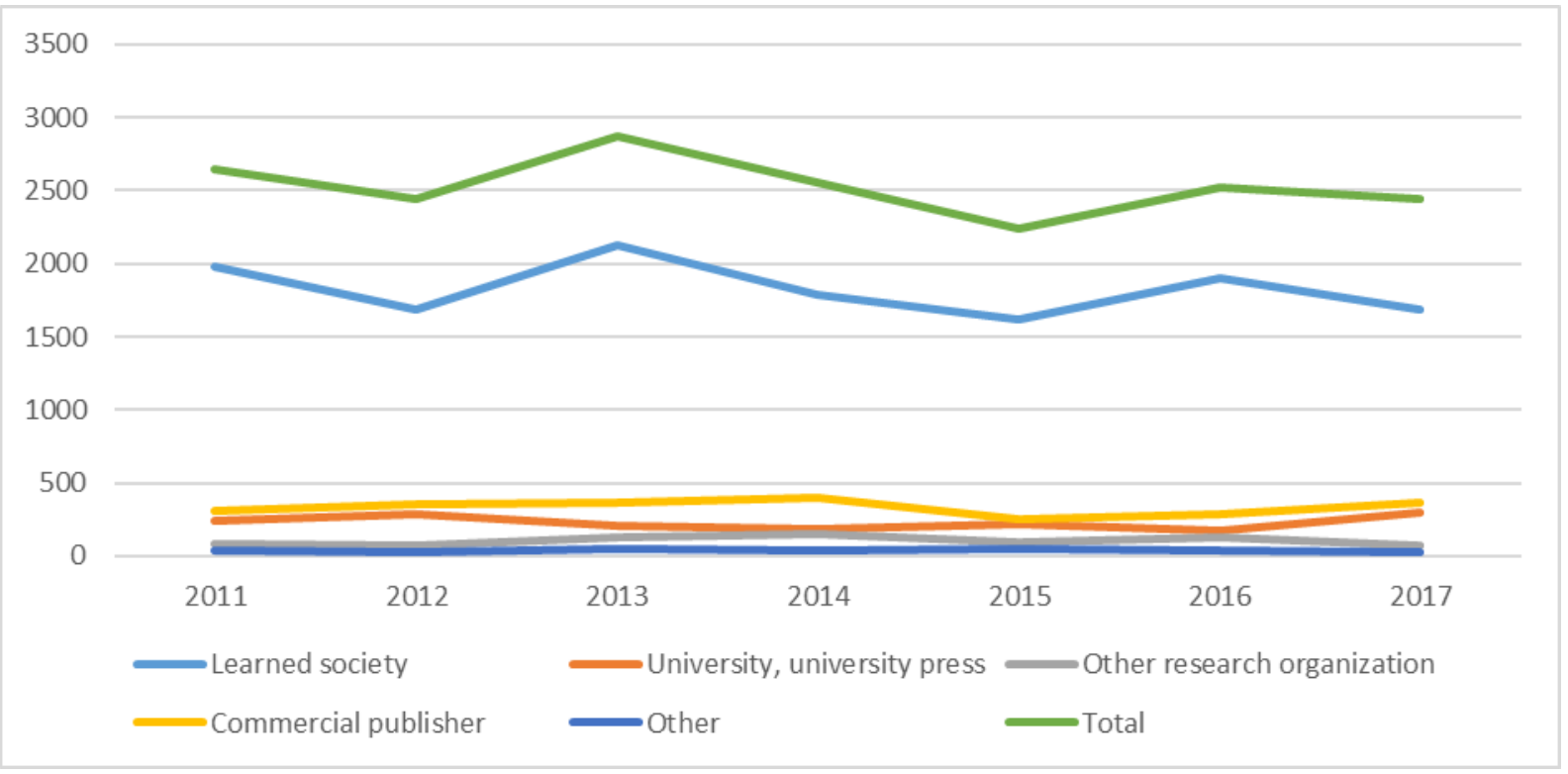

Figure 1. Finnish publishers' yearly output 2011-2017 ( $N=17724)$.

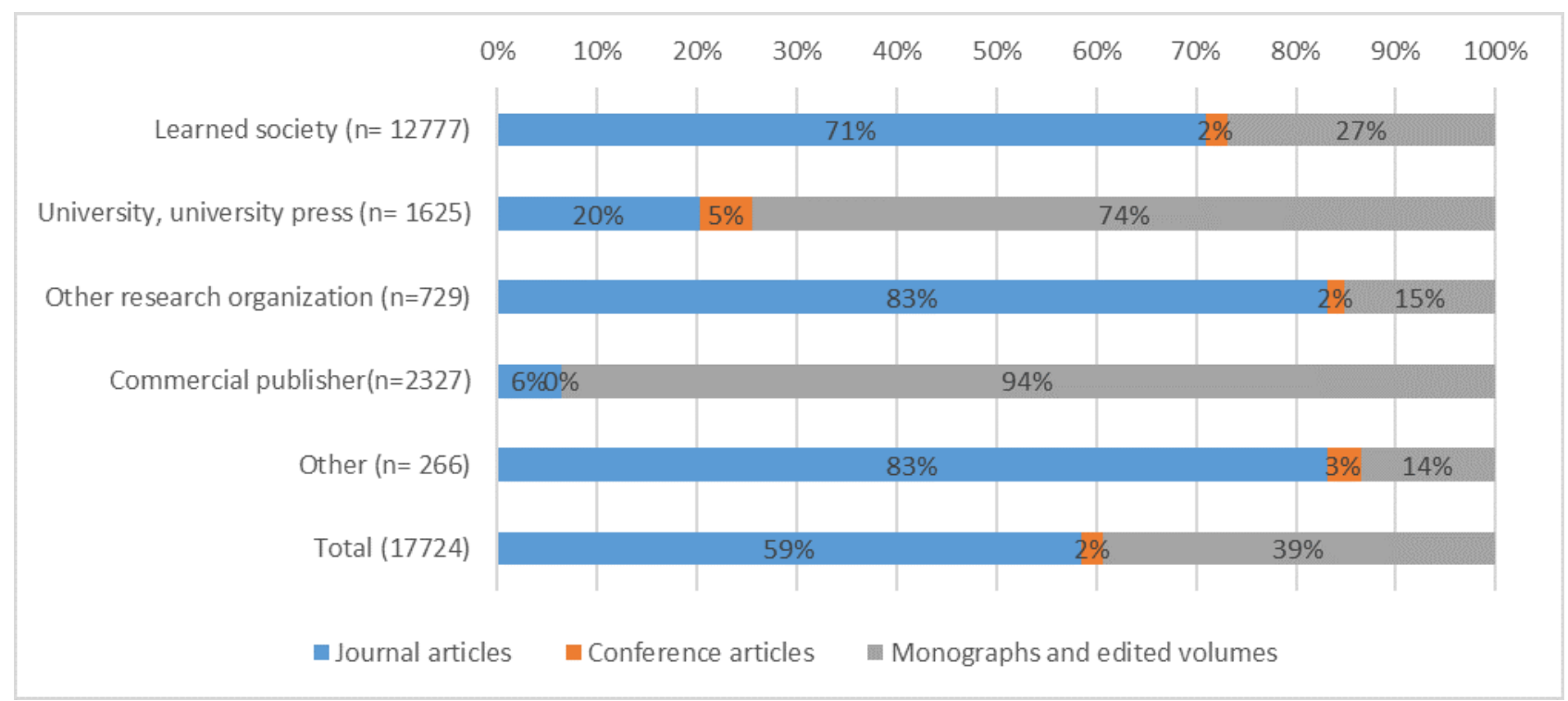

Figure 2. Peer-reviewed publication output from Finnish universities published by Finnish publishers in 2011-2017 (N=17724).

\section{Disciplinary differences}

Finnish peer-reviewed publications were clearly focused on social sciences (39\% of the publications), humanities (36\%) as well as medical and health sciences (16\%) (Figure 3 ). Only $6 \%$ of the publications were from natural sciences, $1 \%$ from technical sciences, and $1 \%$ from agriculture and forestry. In the social sciences and humanities, the two largest channels are book series in the borderline of scholarly publications and those intended for professional and general audiences: Studia Biographica contains relatively short biographies and Kko:n ratkaisut kommentein contains Supreme Court Decisions with commentary. Almost one third of the book publications published by learned societies were published in these two series. Fluctuation in the annual number of outputs by learned societies (Figure 1 ) is actually largely due to Studia biographica. In medical sciences national publishing in Finland is heavily focused on two journals Duodecim and Finnish 
Medical Journal (Suomen lääkärilehti). More than $60 \%$ of the output in medical and health sciences were published in Finland in these two journals.

Publishers were also profiled differently from the point of view of disciplines (Figure 3). Learned societies published most actively in humanities, social sciences and medical and health sciences. Universities and university presses and commercial publishers focused almost totally on humanities and social sciences. $75 \%$ of the publications published by commercial publishers were for social sciences. Other research organizations and other publishers were active in natural sciences because of two high volume publications (Boreal environment research and Annales zoologici Fennici). There was also scholarly publishing activity in the state research institutes focusing on natural sciences. However, the number of publications published in Finland in natural sciences was relatively low.

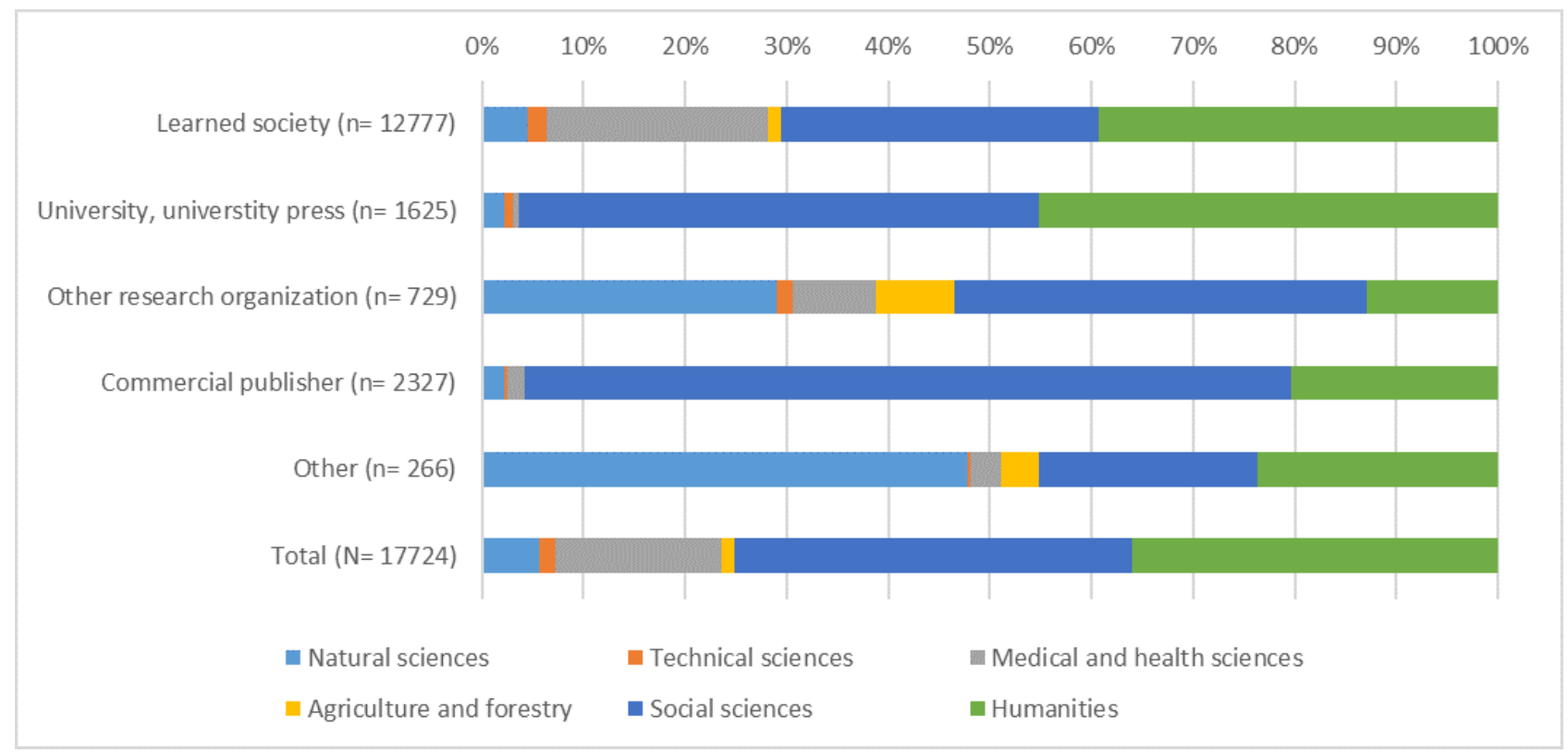

Figure 3. Type of outputs by publisher $(N=17724)$

\section{Open access in Finnish publications}

We examined the share of open access (OA) in Finnish peer-reviewed publications from Finnish universities in 2016-2017. The total number of publications was 4969. The share of openly available peer-reviewed outputs was $42 \%$ (Figure 4). The share of OA was highest for universities and university presses and other research organizations. A little over $38 \%$ of learned society publications were OA. The share of OA was lowest for commercial publishers (20\%).

We also examined the share of OA between different peer-reviewed publishing channels. In 2016-2017 17.7\% of book publications and $44.2 \%$ of journals/book series were OA. 


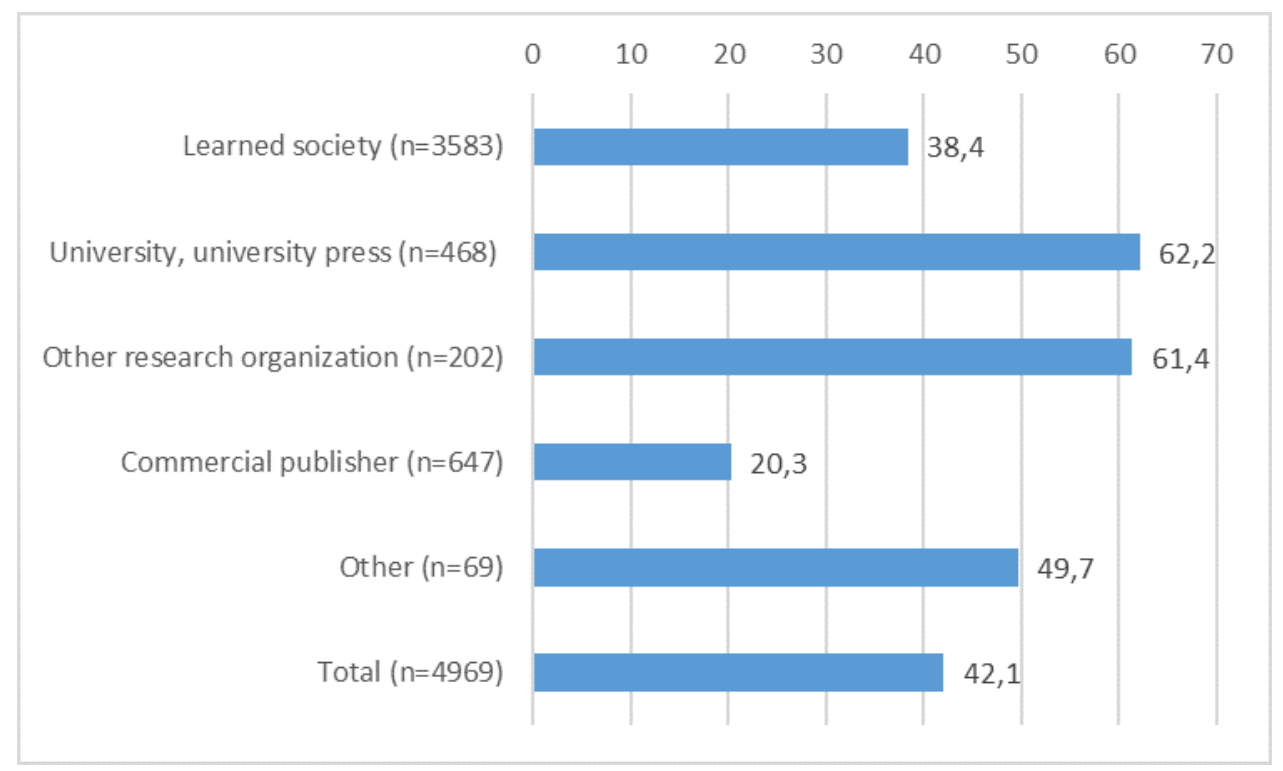

Figure 4. Share of open access (\%) Finnish peer-reviewed publications in 2016-2017 (n=4969).

\section{DISCUSSION AND CONCLUSIONS}

Our results show that learned societies have a strong role in national scholarly publishing in Finland. Approximately $70 \%$ of peer-reviewed publication channels and outputs are published by learned societies. There were 202 learned societies that published at least one journal or book series. The share of journals published by commercial publishers is significantly lower in Finland compared to international publications (Ware \& Mabe 2012, 33). Finland is a small Nordic country with on average 5.5 million inhabitants. National publication channels that publish articles and books mainly in Finnish reach only the small language area within Finnish speakers. Thus, it is not surprising that foreign commercial publishers have not been keen to enter the market with little hope of profits. Luckily, Finnish government is willing to support research activities and also domestic journals.

In the UK, many learned societies publish in co-operation with commercial publishers or university presses (UUK, 2015, 67). This is not the case in Finland however. In Finland, learned societies still publish journals inhouse and none of the big commercial publishers in Finland publish journals. However, commercial publishers have a strong role in monograph publishing in Finland. Two of the biggest commercial publishers published one fourth of all scholarly books in Finland. We may also note that international book publishers, such as Springer, have no publishing activity in Finland, apparently because of the small market for Finnish and Swedish language scholarly books. Consequently, national language publishing is entirely dependent of Finnish scholarly publishers. This is probably the case in other small language areas.

Results also indicate that the majority of the outputs by society publishers come from humanities and social sciences. In fact, most of the domestic publications in Finland come from these fields. It has been widely recognized that publishing patterns differ between disciplines and disciplinary groups (e.g. Becher, 1989; Whitley, 1984; Kyvik, 1991; Piro et al., 2013). Publishing practices in humanities and social sciences favor national publishing while publishing in e.g. natural sciences and medicine is focused on international publications (Kyvik, 1991; Kulczycki et al., 2018). Scholars also read more national publications in humanities and social sciences (Late et al., 2019). This is explained with lower degree of mutual dependence between scholars in social sciences and humanities (Whitley, 1984). Research topics in social sciences and humanities 
are often local in nature and spark more interest among domestic audiences. Furthermore, research topics in these fields may also be of interest to a wider audience than just academic peers.

According to our results, approximately $40 \%$ of the scholarly publications published in Finland are open access. The share of OA on society channels was larger than with commercial publishers but smaller than with university publishers. The share of $O A$ in Finnish publications is similar to earlier international studies (e.g. Piwowar et al., 2018). However, Björk (2019) estimated that only $30 \%$ of Finnish peer reviewed journals are OA. Since our analyses were based on the number of Finnish peer-reviewed publications from Finnish universities in 2016-2017, the two studies are not comparable. Transition to open access has been a difficult task for many national scholarly publishers. Although Finnish journals published by the societies are often not-for-profit their income model has been based on subscriptions and government subsidies. In a small country and small language area, journals rarely generate economic profit, which is why cooperation with commercial publishers is unlikely. The situation may be different in larger language areas (Wise \& Estelle, 2019). In Finland the government has supported digitalization of national journals by launching journal management and publishing service using Open Journal Systems software (journal.fi).

Nevertheless, before moving to open access or launching new OA journals, journals need to have a stable business model. In Finland, there has been a long discussion about the income model for domestic scholarly journals. However, the discussions are continuing without consensus (Ilva, 2018). Plan S will put pressure to the discussion of the funding of the domestic journals in all European countries. Since the majority of the Finnish journals are published by learned societies, societies have a critical role in realizing Plan $S$ in Finland. However, there is a concern that the criteria for open access publishing cannot be met by small learned societies. Especially in small non-English-speaking countries where multilingualism of scholarly communication is at stake (Helsinki Initiative 2019). Instead of using the same criteria for every type of publisher, modifications might be needed. Moreover, most attention in debates surrounding Plan $\mathrm{S}$ and society publishers has focused on journal publishing. Societies also publish peer-reviewed edited volumes and monographs that play an important role in scholarly communication in the social sciences and humanities. After all, some of the publishing channels of national learned societies are well-known - some even on international level.

Learned societies have gained some research interest in earlier studies. However, considering the critical role of learned societies in scholarly publishing, more research is needed. It is important to study the role of learned societies in scholarly publishing in other countries. It would be interesting to compare our findings from Finland to those from other countries. There is also a need for more holistic studies concerning the role and identities of learned societies. Hewitt et al. (2017) and Delicado et al. (2014) studied the roles of learned societies in the UK and Portugal. However, it would be important to gain knowledge about the situation on learned societies in other countries as well. In addition, the influence of Plan S for learned societies should be followed closely in the future.

\section{REFERENCES}

Academy of Finland. (2018, 4 September). Academy of Finland welcomes Plan S for achieving full open access [Press release]. Retrieved 7 August 2019, from https://www.aka.fi/en/about-us/media/pressreleases/2018/academy-of-finland-welcomes-plan-s-for-achieving-full-open-access/

Auranen, O. \& Pölönen, J. (2012). Classification of scientific publication channels: Final report of the Publication Forum project (2010-2012). Federation of Finnish Learned Societies.

http://www.julkaisufoorumi.fi/sites/julkaisufoorumi.fi/files/publication_forum_project_final_report_0.pdf 
Becher, T. (1989). Academic tribes and territories. Intellectual enquiry and the cultures of disciplines. Milton Keynes: The Society for Research into Higher Education \& Open University.

Björk, B. C. (2019). Open access journal publishing in the Nordic countries. Learned Publishing, early view.

Brainard, J. (2019). Scientific societies worry about threat from Plan S. Science, 363(6425), 332-333. DOI: 10.1126/science.363.6425.332

Clarke, M. (2018, 5 December). Plan S: Impact on society publishers [blog post]. Retrieved 21 January 2019, from https://scholarlykitchen.sspnet.org/2018/12/05/plan-s-impact-on-society-publishers/

cOAlition S. (2019, 31 May). Accelerating the transition to full and immediate Open Access to scientific publications. Retrieved 7 August 2019, from https://www.coalition-s.org/wp-

content/uploads/PlanS Principles and Implementation 310519.pdf

Csiszar, A. (2017). How lives became lists and scientific papers became data: cataloguing authorship during the nineteenth century. British Journal of History of Science, 50(1), 23-60.

Delicado, A., Rego, R., Conceição, C. P., Pereira, I., \& Junqueira, L. (2014). What roles for scientific associations in contemporary science? Minerva, 52(4), 439-465. https://doi.org/10.1007/s11024-014-92603

de Solla Price, D. J. (1963). Little science, big science. New York: Columbia University Press

Federation of Finnish Learned Societies. (2018). Tieteellisten seurain valtuuskunta. Toimintakertomus vuodelta 2018. [Federation of Finnish Learned Societies. Annual report 2018.] Retrieved 8 August 2019, from https://www.tsv.fi/sites/tsv.fi/files/media/TSV toimintakertomus 2018.pdf

Finch report. (2012). Accessibility, sustainability, excellence: how to expand access to research publications. Report of the Working Group on Expanding Access to Published Research Findings. Retrieved 7 August 2019, from https://www.acu.ac.uk/research-information-network/finch-report-final

Fyfe, A., Coate, K., Curry, S., Lawson, S., Moxham, N., \& Røstvik, C. M. (2017). Untangling academic publishing: A history of the relationship between commercial interests, academic prestige and the circulation of research. https://doi.org/10.5281/zenodo.546100

Helsinki Initiative on Multilingualism in Scholarly Communication (2019). Helsinki: Federation of Finnish Learned Societies, Committee for Public Information, Finnish Association for Scholarly Publishing, Universities Norway \& European Network for Research Evaluation in the Social Sciences and the Humanities. https://doi.org/10.6084/m9.figshare.7887059.

Hewitt, M., Dingwall, R., \& Turkmendag, I. (2017). More than research intermediaries: a descriptive study of the impact and value of learned societies in the UK social sciences. Science and Public Policy, 44(6), 775788.

Hopkins, J. (2011). The role of learned societies in knowledge exchange and dissemination: the case of the Regional Studies Association, 1965-2005. History of Education, 40(2), 255-271.

https://doi.org/10.1080/0046760X.2010.518161

Houghton, B. (1975). Scientific periodicals: their historical development, characteristics and control. London: Bingley

Ilva, J. (2017). Towards reliable data - counting the Finnish Open Access publications. Procedia Computer Science 106, 299-304. https://doi.org/10.1016/j.procs.2017.03.029 
Ilva, J. (2018). Looking for commitment: Finnish open access journals, infrastructure and funding. Insights, 31(25), 1-9. https://doi.org/10.1629/uksg.414

Johnson, R., \& Fosci, M. (2015). On shifting sands: assessing the financial sustainability of UK learned societies. Learned Publishing, 28(4), 274-281. https://doi.org/10.1087/20150406

Johnson, R., Watkinson, A. \& Mabe, M. (2018). The STM report: An overview of scientific and scholarly publishing. 5ht edition. October 2018. The Hague, Netherlands: International Association of Scientific, Technical and Medical Publishers. Retrieved from https://www.stmassoc.org/2018 1004 STM Report 2018.pdf

Kulczycki, E., Engels, T.C.E., Pölönen, J., Bruun, K., Dušková, M., Guns, R., Nowotniak, R., Petr, M., Sivertsen, G., Istenič Starčič, A. \& Zuccala, A. (2018). Publication patterns in the social sciences and humanities: The evidence from eight European countries. Scientometrics, 116(1), 463-486.

Kulczycki, E., Mustajoki, H., Pölönen, J. \& Røeggen, V. (2019). Polyglots need protection. Research Europe, 498: 12. https://www.researchresearch.com/news/article/?articleld=1381733.

Kyvik, S. (1991). Productivity in academia. Scientific publishing at Norwegian universities. Oslo: Universitetsforlaget.

Larivière, V., Haustein, S., \& Mongeon, P. (2015). The oligopoly of academic publishers in the digital era. PloS One, 10(6), e0127502. https://doi.org/10.1371/journal.pone.0127502

Late, E., Tenopir, C., Talja, S., \& Chirstian, L. (2019). Reading practices in scholarly work: from articles and books to blogs. Journal of Documentation, 75(3), 478-499.

Mabe, M. (2009). Scholarly Publishing. European Review, 17(1), 3-22. doi:10.1017/S1062798709000532

Martín-Martín, A., Costas, R., van Leeuwen, T., \& Delgado López-Cózar, E. (2018). Evidence of Open Access of scientific publications in Google Scholar: a large-scale analysis. Journal of Informetrics, 12(3), 819-841. https://doi.org/10.1016/j.joi.2018.06.012

McCarthy, D., \& Rands, M. (2013). Learned societies: a bridge between research, policy making and funding. Studies in Higher Education, 38(3), 470-483. https://doi.org/10.1080/03075079.2013.773216

Meadows, A. J. (1974). Communication in science. London: Butterworths.

UUK. (2015). Monitoring the transition to open access. Universities UK. Retrieved from

https://www.universitiesuk.ac.uk/policy-and-analysis/reports/Pages/monitoring-transition-open-access2015.aspx

Monitoring the transition to open access. (2017). Universities UK. Retrieved from https://www.universitiesuk.ac.uk/policy-and-analysis/reports/Pages/monitoring-transition-open-access2017.aspx

Morris, S. (2001). What's so special about not-for-profit publishers? Learned Publishing, 14(3), 163-165.

Piro, F., Aksnes, D. \& Rørstad, K. (2013). A macro analysis of productivity differences across fields:

Challenges in the measurement of scientific publishing. Journal of the American Society for Information Science and Technology 64(2), 307-320.

Piwowar H, Priem J, Larivière V, Alperin JP, Matthias L, Norlander B, Farley A, West J, Haustein S. 2018. The state of OA: a large-scale analysis of the prevalence and impact of Open Access articles. PeerJ 6:e4375. https://doi.org/10.7717/peerj.4375 
Publication Forum. (2019, 19 February). Retrieved 6 August 2019, from https://www.julkaisufoorumi.fi/en/publication-forum

Pölönen, J. (2018). Applications of, and Experiences with, the Norwegian Model in Finland, Journal of Data and Information Science 3:4 (2018) 31-44. https://doi.org/10.2478/jdis-2018-0019

Sīle, L., Guns, R., Sivertsen, G., \& Engels, T. C. E. (2017). European Databases and Repositories for Social Sciences and Humanities Research Output. ECOOM \& ENRESSH: Antwerp.

Sīle, L., Pölönen, J., Sivertsen, G., Guns, R., Engels, T. C. E., Arefiev, P., Dušková, M., Faurbæk, L., Holl, A., Kulczycki, E., Macan, B., Nelhans, G., Petr, M., Pisk, M., Soós, S., Stojanovski, J., Stone, A., Šušol, J. \& Teitelbaum, R. (2018). Comprehensiveness of national bibliographic databases for social sciences and humanities: findings from a European survey, Research Evaluation, 4(1), 310-322.

https://doi.org/10.1093/reseval/rvy016

Sivertsen, Gunnar (2018). Balanced multilingualism in science, BiD: textos universitaris de biblioteconomia i documentació, n. 40 . <http://bid.ub.edu/en/40/sivertsen.htm>. DOI:

http://dx.doi.org/10.1344/BiD2018.40.25

TBI Communications. (2014). Learned society attitudes towards open access: report on survey results. May 2014. EDP Sciences. Retrieved from https://www.edpopen.org/images/stories/doc/EDP_Society_Survey_May_2014_FINAL.pdf

Ware, M., \& Mabe, M. (2012). The STM report: An overview of scientific and scholarly journal publishing. November 2012. The Hague, Netherlands: Association of Scientific, Technical and Medical Publishers. Retrieved from http://www.stm-assoc.org/2012 1211 STM Report 2012.pdf

Whitley, R. (1984). The intellectual and social organization of the sciences. Oxford: Clarendon Press.

Wiley membership survey. (2015). Membership matters: lessons from members and non-members. March 2015. Retrieved from http://news.wiley.com/exchanges-survey-whitepaper

Willinsky, J. (2006). The access principle: the case for open access to research and scholarship. Cambridge (Mass.): MIT Press.

Wise, A., \& Estelle, L. (2019). Towards transition strategies and business models for Society Publishers who wish to accelerate Open Access and Plan S. figshare. Online resource.

https://doi.org/10.6084/m9.figshare.8398406.v1 